\title{
Inventories Accounting under US-GAAP and IFRS Standards: The Differences That Hinder the Full Convergence
}

\author{
Manuela Lucchese ${ }^{1} \&$ Ferdinando Di Carlo ${ }^{2}$ \\ ${ }^{1}$ Department of Economics, University of Campania "Luigi Vanvitelli”, Capua (CE), Italy \\ ${ }^{2}$ Department of Mathematics, Computer science and Economics, University of Basilicata, Potenza, Italy \\ Correspondence: Manuela Lucchese, Department of Economics, University of Campania "Luigi Vanvitelli", \\ Corso Gran Priorato di Malta, Capua (CE), Italy. E-mail: manuela.lucchese@unicampania.it
}

Received: May 29, 2020

doi:10.5539/ijbm.v15n7p180
Accepted: June 20, 2020

Online Published: June 23, 2020

URL: https://doi.org/10.5539/ijbm.v15n7p180

\begin{abstract}
This study purposes of understanding the existing differences between US-GAAP and IFRS accounting treatments of inventory. Given the 2015 FASB update, aimed at simplifying and aligning inventory accounting with IFRS standards, the research explores the introduced innovations. More specifically, the study, starting from a literature review and standards analysis, designs a theoretical framework aimed at facilitating the understanding of the differences still existing between the two accounting principles. Different from the prior works, we focus on the complex determination of the net realizable value in the case of input (e.g., raw materials) write-down. In particular, we show how the net realizable value (NRV) changes according to the value taken as a reference. The results of this analysis suggest that, based on a prudential valuation logic, the replacement cost is the best estimate for NRV.
\end{abstract}

Keywords: inventories, valuation, IFRS, US GAAP, net realizable value, financial statement

\section{Introduction}

Over the last few decades, the convergence process of accounting rules between IFRS standards and US GAAP has attracted great attention from regulators, investors, and other stakeholders. Since 2002, issuing the Norwalk Agreement, FASB, and IASB (hereafter, "the Boards") have been working closely together to adopt a single set of high-quality, globally-accepted-accounting standards for making their financial statements comparable (Lin, Riccardi,, Wang, Hopkin, \& Kabureck, 2018; Street \& Gray, 1999). This need is current again and highlighted by some practitioners (PwC, 2019b, pp. 1-2).

At present, the convergence process is still ongoing (Baudot, 2018; Camfferman \& Zeff, 2018). De Luca and Prather-Kinsey (2018), assuming that "adoption" means that a jurisdiction incorporates IFRS, as issued by the IASB, instantly as its national accounting system, highlight that the IASB has only gained pseudo-"adoption" (not as published by the IASB) of its standards by many but not all countries. In other terms, there was not a global legitimacy of the IASB, the "generalized perception or assumption that the actions of an entity are desirable, proper or appropriate within some socially constructed system of norms, values, beliefs, and definitions" (Suchman, 1995).

In the USA, the due process of the FASB states that national authority to adopt, police, and enforce compliance with US-GAAP is the Securities and Exchange Commission (SEC). For this reason, during these last decades, the IASB has achieved a recognized and respected accounting board and an internationally recognized due process. In fact, for specialized rulemaking bodies, this technical competence is a necessary condition to establish legitimacy with constituencies, but this may not be sufficient to gain legitimacy because of the relevance of political aspects (Richardson \& Eberlein, 2011).

Starting from these assumptions, we focus our attention on the convergence process of the accounting treatment of Inventories, under IFRS (IAS 2) and US-GAAP (ASU 330 and ASU 2015-11).

The two international standards have been appearing almost similar prima facie. Correctly, both Boards applied a traditional approach adapted to the use of historical cost, preferring a prudential valuation logic (Bao, Lee \& Romeo, 2010; Barker \& McGeachin, 2015), contrary to the increasingly widespread use of the fair value for the accounting treatment of other items (Penman, 2007; Shanklin, Hunter \& Ehlen, 2011; Alexander, 2012; Barth, 
2014; Barker \& Schule, 2017). As Barker and Teixera (2018) pointed out, this cost-based approach is justified because "inventory typically cannot be sold to a customer, except by making extensive use of the entity's other economic resources (for example, in production and marketing activities)."

Nevertheless, in 2003, the two standards presented two main differences:

First, IAS 2 (2003), contrary to the US-GAAP, does not allow the use of the LIFO method (last-in-first-out) in determining the cost of inventories.

Second, but most important, under IAS 2 (2003), the inventories are evaluated at the lower of cost or net realizable value (LCNRV), while under Accounting Research Bulletin 43 Chapter 4 (ARB 43, No. 4 ), the stocks are assessed at the lower of cost or market (LCM). In 2015, the FASB amended the standard Inventory (ASU 2015-11) to adopt a uniform set of standards and to simplify inventory measurements. This update aligns US GAAP with IFRS only for entities with inventory costs determined by a method other than the last-in-first-out (LIFO) or retail inventory method (RIM) (Penner, Kreuze \& Langsman, 2016).

Therefore, FASB assumes a two-tier approach for the accounting treatment of inventory (Harris \& Ananthanarayanan, 2019), which could be defined as being an "accounting loophole", questioning the real simplification and convergence of its update. As a result, a US entity could evaluate inventories:

- under other methods (e.g., first-in-first-out, FIFO, weighted average cost (WAC) methods, etc.) and thus use the general principle of lower of cost or net realizable value (LCNRV), consistent with IAS 2;

- under LIFO or RIM and so apply the general rule of lower of cost or market (LCM).

Based on these premises, the study provides the effectiveness of the convergence process in terms of the comparability and theoretical value adopted. Accurately, using the value measurement theories, the research illustrates the differences resulting from a different accounting treatment of the inventories when US entities employ the option to use LIFO or RIM and evaluate them at the LCM, and the real effectiveness of the convergence process.

The paper is novel because it compares the accounting treatment of inventories under IFRS and US GAAP post emendation of the ASU 2015-11 and highlights the cases in which the evaluation of the stocks produce a different impact on the entity's financial statements under IFRS and US-GAAP.

The results of this paper are directed to the academic community, practitioners, and policymakers as theoretical and practical advances.

The remainder of the paper is organized as follows. Section 2 examines the theoretical framework represented by the differences deriving from the comparison of the two standards, the primary literature on the cost formulas and of the value measurement theories employed for the inventories accounting treatments required under IAS 2 and ASU 2015-11. Section 3 discusses the different scenarios that could evidence when similar entities operate under IAS 2 or US-GAAP standards. Section 4 contains the conclusions.

\section{Theoretical Framework}

\subsection{Inventories under IFRS and US GAAP: Main Differences}

In 2015 the FASB disposed of realigning the US-GAAP (ASU 2015-11) on Inventories to the IAS 2. The revised standard required that the inventories are evaluated at the LCNRV at the end of the period (Flood, 2019).

Nevertheless, the updated ASU 2015-11 does not lead to a real alignment between the two standards. Indeed, the US standard provides for an exception to LCNRV rule: inventory measured using LIFO or RIM are excluded from the simplification adopted and evaluated at the LCMI.

Therefore, there are still two main differences between the two accounting principles (Penner et al., 2016; Harris \& Ananthanarayanan, 2019).

First, LIFO is still allowed by US-GAAP (Street \& Gray, 1999; Bao et al., 2010), while it is prohibited by IFRS (Reneiking et al., 2012). Although, in this case, the SEC (Securities and Exchange Commission) and IRC (Internal Revenue Code) imposed some limitations, respectively: "the LIFO reserve" and "the conformity rule" (Husband, 1940; Cushing \& LeClere, 1992; Gray \& Ehoff, 2014).

Second, subsequent measurement is unchanged for inventory using LIFO or RIM. Under US GAAP, they apply LCM rule, while LCNRV is the unique option allowed by IFRS (Bao et al., 2010; Sedki, Smith \& Strickland 2014; Flood, 2019). Table 1 summarises the key differences between ASU 2015-11 and IAS 2. 
Table 1. Key differences between US GAAP and IFRS Standards in accounting for inventories

\begin{tabular}{l|ll}
\multicolumn{4}{c}{ IFRS Standards } & \multicolumn{1}{c}{ U.S. GAAP } \\
\hline Cost formulas & $\begin{array}{l}\text { The same cost formula must to be } \\
\text { applied to all inventories that have } \\
\text { a similar nature and use to the } \\
\text { entity }\end{array}$ & $\begin{array}{l}\text { The same cost formula does not need } \\
\text { to be applied to all inventories that } \\
\text { have a similar nature and use to the } \\
\text { entity }\end{array}$ \\
LIFO method & Is not permitted & $\begin{array}{l}\text { Is permitted } \\
\text { (please note conformity rule and } \\
\text { LIFO reserve) }\end{array}$ \\
Subsequent measurement & LCNR & $\begin{array}{l}\text { For inventory measured by LIFO or } \\
\text { RIM: LCM }\end{array}$ \\
& $\begin{array}{l}\text { For inventory measured by any } \\
\text { method other than LIFO or RIM: } \\
\text { LCNR }\end{array}$ \\
Reversal of write-downs & $\begin{array}{l}\text { Are required for subsequent } \\
\text { recoveries (limited to the amount of } \\
\text { the inventory's original cost) }\end{array}$ & \\
& &
\end{tabular}

Source: Bao et al., (2010), Gray \& Ehoff (2014), Penner et al. (2016), Deloitte (2019), PwC (2019a).

\subsection{Inventories Accounting Treatments: Primary Measurement and Cost Formulas}

Inventories are initially measured at purchase/production cost that shall include all direct and overhead expenditures of getting stocks ready for sale. Additional fees, storage costs, and other administrative expenses are not included (Alibhai, Bakker \& Balasubramanian, 2019).

Then, when they are sold, the carrying amount of these is recognized as an expense. For ordinarily interchangeable items, it could be difficult for the entity to determine the specific cost because of (a) high inventory turnover rate and (b) large numbers of the items. For overcoming the issue, it may be used cost-flow assumptions (Biddle, 1980; Gray \& Ehoff, 2014), such as LIFO, FIFO, or WAC. These formulas may or may not reflect the actual physical flow of the inventory (Flood, 2019).

As the name suggests, the FIFO (first-in, first-out) method works under the assumption that items bought or produced first are the items sold or used first, regardless of the actual physical flow. Consequently, the items remaining in inventory at the end of the period are those most recently purchased or produced. For this reason, FIFO appears as the closest approximation to actual cost flows (Biddle, 1980; Sedki et al., 2014).

Under the WAC method, the cost of each item is determined by dividing the cost of goods available for sale by the number of units available for sale. The average may be calculated periodically, or as each additional shipment is received, depending upon the circumstances of the entity (Alibhai et al., 2019).

As the name suggests, the LIFO (last-in, first-out) method works under the assumption that the latest inventory that was purchased will be the first to be sold, regardless of the actual physical flow. Consequently, the items remaining in stock at the end of the period are those less recently purchased or produced (Biddle, 1980; Houmes, Dickins \& O'Keefe, 2012).

The choice of cost-flow method has a significant impact on ending inventory on the balance sheet (Giganti, 1990; Simeon \& John, 2018; Flood, 2019). Under the LIFO method, the balance sheet shows inventories at outdated prices (Henry \& Holzmann, 2010). While LIFO net income provides a timelier measure of firm performance (Houmes et al., 2012: 235), the last inventory items in the balance sheet tend to age and could potentially become obsolete (Li \& Sun, 2016). Furthermore, as several authors pointed out, inventories assessed with the LIFO method rarely correspond to the actual physical flow of goods (Reinstein, Alvin \& Vangermeersch, 2008; Bao et al., 2010). Since LIFO favors the current net income information over current stocks value information, it is defined as an income-statement-oriented method (Flood, 2019). Conversely, FIFO does not provide the most explicit measure of periodic net income. Nevertheless, it is considered to reflect the current cost of inventory on the balance sheet and so to give investors a more useful inventory value (Sedki et al., 2014). As a result, FIFO is a balance-sheet-oriented method (Flood, 2019).

Given that, some scholars have associated the IASB choice of rejecting LIFO with the IASB shift from a revenue-expenses view to an asset-liability view: while the first focuses on end-period amounts, the second focuses on the account balance on a day-to-day basis (Reineking et al., 2012). The asset-liability view requires that figures on the financial statement represent the most relevant information regarding time (Reineking et al., 2012). Since the LIFO gives to the balance sheet older layers and values (Bao et al., 2010), IFRS looks at LIFO valuations as outdated information, not relevant for financial reporting (Henry \& Holzmann, 2010). Furthermore, 
while US GAAP does not aim to achieve a match between the inventory method adopted by a company and the actual physical flow of the goods (Bao et al., 2010), IFRS aims to confirm the latter with the assumed flow of costs into and out of inventory (Henry \& Holzmann, 2010).

In the US scenario, although the elimination of LIFO method was suggested by the Obama administration's budget proposals (Gray, 2013; Li \& Sun, 2016), it is still permitted under the recent updated ASU 2015-11.

Consistent with several authors (Husband, 1940; Jennings, Simko \& Thompson II, 1986; Dopuch \& Pincus, 1988; Cushing \& LeClere, 1992), the most explanatory reason for the LIFO choice lies in its tax benefits. Indeed, Gray and Ehoff (2014) defined LIFO as "a taxing matter." When an entity elects LIFO, its ending inventories are underestimated, the cost of goods sold is overestimated. Therefore, pre-tax income will be lower, resulting in a lower tax expense. According to this, several authors have defined LIFO as a "tax loophole" or "accounting manipulation" (Dopuch \& Pincus, 1988).

Given these considerations, both SEC and IRC have imposed two limitations to "LIFO manipulation", respectively: the LIFO reserve and the conformity rule (Husband, 1940).

The LIFO reserve consists of the differences between reported amount under LIFO and FIFO method, reported in the entity's notes (Jennings et al., 1986; Li \& Sun, 2016). Because a company may employ LIFO for tax purposes, this reserve represents this deferred taxable income amount (Reineking et al., 2012). Or else, it represents the total amount that a firm's net income has been reduced since LIFO adoption (Houmes et al., 2012). Coffee, Roig, Lirely \& Little (2010) have defined it as "a direct indicator of the materiality of the balance sheet distortions, which may result from LIFO use over a period of time."

The conformity rule requires that if LIFO is chosen for tax purposes, it must still be used for financial reporting purposes (Sedki et al., 2014; Harris \& Ananthanarayanan, 2019).

Even though LIFO is still the key to non-convergence (Henry \& Holzamann, 2010), some scholars have pointed out that the gap between IFRS and US GAAP has decreased in practice. The LIFO benefits (tax savings) depend on an inflationary period. During the 21st-century, when the level of inflation has become minimal, more entities have decided to stop using LIFO and shift to another valuation method to align more closely with IFRS (Gray \& Ehoff, 2014).

Guenther and Sansing (2012), instead, have argued that this reducing number of entities that utilize LIFO acts as an incentive for other US companies to elect LIFO. "Every firm would prefer for other firms to use FIFO [...] because in these circumstances [...] each firm has an incentive to choose LIFO [...] getting both the tax benefits of LIFO for itself while also benefiting from the reduced quantities and higher prices associated with every other firm choosing FIFO" (Guenther \& Sansing, 2012, p. 1590).

Anyway, the updated US standard continues to maintain the discretion for the companies to select the LIFO method and, consequently, to apply the LCM principle. Table 2 summarises the pros and cons of the LIFO method.

Table 2. Pros and Cons of the LIFO method

\begin{tabular}{l|l}
\multicolumn{2}{c}{ Pros of LIFO } \\
$\begin{array}{l}\text { Lower net income and thus income taxes, especially } \\
\text { during period of rising prices (Dopuch and Pincus, } \\
\text { 1988, Reineking et al., 2012, Flood, 2019, Deloitte, } \\
\text { 2019, PwC, 2019a, 2019b) }\end{array}$ & $\begin{array}{l}\text { Manipulation of income and distortion of truth } \\
\text { (Husband, 1940) }\end{array}$ \\
$\begin{array}{l}\text { Best measure of gross profit, matching of current } \\
\text { cost with the current revenues (Flood, 2019) }\end{array}$ & $\begin{array}{l}\text { Misrepresents market conditions and up-to-date } \\
\text { informations (Reineking } \text { et al., 2012) }\end{array}$ \\
$\begin{array}{l}\text { Lack of possibility for U.S. multinational } \\
\text { companies to guarantee continuity among their } \\
\text { inventory valuation (Locascio, 2017) }\end{array}$ & $\begin{array}{l}\text { Failure to match physical flow, cost flow and } \\
\text { financial records (Husband, 1940, Reinstein A. et } \\
\text { al., 2008, Flood, 2019) }\end{array}$ \\
\end{tabular}

Source: Authors' 


\subsection{Value Measurement Theories in the Valuation of Inventories: A Summary of the Principal Evaluation Criteria}

Before examining the evaluation criteria indicated by the standards in detail, we recall main value measurement theories related to top evaluation approaches mentioned.

Assuming that the valuation of inventories under both accounting principles follows a prudential/conservative approach (Bao et al., 2010; Gray \& Ehoff, 2014; Barker \& McGeachin, 2015; Barker \& Teixera, 2018), in this section, we discuss just the configurations of the value indicated in the standards, respectively: historical cost, net realizable value and replacement cost.

The historical cost (HC) represents the economic sacrifice expressed in monetary terms, for the purchase of goods and services following a "critical event", the market transaction (Myers, 1959). The latter - underlying the realization principle (Edwards, 1975) - gives certainty to the event and, therefore, to the economic value sustained, legitimizing its recognition in accounting (Horngren, 1965).

Referring to inventories, as assets, $\mathrm{HC}$ is a past amount reported on the present balance sheet (Sterling, 1981). To management, it represents an investment (Littleton, 1952). Its benefit is expected to be greater than the sacrifice; otherwise, if a cost will not benefit the future, then it should not be capitalized, should not be recorded as an asset, should be expensed (Sterling, 1981). In this sense, the HC is formulated considering the expectations of future values to be received from the economical use of an acquired asset. However, it can not be considered an expression of the current value of the future expected benefits (Sterling, 1981).

Specifically, Littleton (1952) states that the word "historical" could tend to negate any idea that account data speak of current or future values. In contrast, the term "invested" fits better. It recalls to values expected by the contracting parties, possible information asymmetries, and exogenous contingencies that may involve specific negotiation (Littleton, 1952, 1953; May, 1952).

Farther, the historical cost represents a more objective transaction measurement than current costs. This is because $\mathrm{HC}$ measurement is based on the actual transaction in which the enterprise participated, while the current cost is based on a hypothetical transaction (Ijiri \& Noel, 1984). However, it does not mean that HC is the "best" accounting measurement. There are two considerations: (i) objectivity differs from reliability, (ii) the "best" measure of the wealth (assets minus liabilities) of a firm does not necessarily correspond to the "best measurement of income" (Ijiri \& Jaedicke, 1966). Thus, on the one hand, current costs provide a more reliable measure of wealth; on the other, historical costs lead to a more reliable income (Ijiri \& Noel, 1984).

The net realizable value (NRV) of an asset is defined as "the maximum net amount which can be realized from the disposal of that asset within a short period of time" where the net amount is defined as "the selling price less disposition costs including tax effects discounted to the point of measurement" (Bedford \& McKeown, 1972).

In the literature, the NRV with the net selling price and the value in use is often also called exit value. The exit value is the current value realizable from the sale (Jones, 2015). It is based on the "current" price at the closing date of the financial year. Thus, exit value means the current exit value, and, unlike the historical cost, it focuses on the present benefit of the cash receivable (Sterling, 1981).

The replacement cost (RC) of an asset is defined as "the cash or cash equivalent that would have to be paid now to acquire resources capable of providing services equivalent to those currently expected to be extracted from the asset" (Bedford \& McKeown, 1972). The RC reflects the current entry value of the economy's resources being employed in the firm (Edwards, 1975; Gee \& Peasnell, 1976).

In a hypothetical perfect market, entry and exit values should not differ (Sterling, 1981). However, due to the existence of frictions in the marketplace, there are significant transaction costs that drive a wedge between entry and exit values, equal to the total amount of commissions (Jones, 2015). Thus, there is a conflict between NRV (exit value) and RC (entry value) (Bedford \& McKeown, 1972).

Based on these assumptions, the issue is whether or not the valuation of assets better serves society for reporting at the cash they command upon sale (current exit value) or at the cash required to have them available for use by the firm (current entry value) (Bedford \& McKeown, 1972). Edwards (1975) states that the point is not whether to value by current entry or exit price, but when to shift from entry to exit values.

The decision, underline Falkenstein and Weil (1977), depends upon which question the statement user wants to answer. On the one hand, the replacement cost tends to answer the question of which is today the asset purchase cost, having services equivalent to those now held and expected to be used, in the least costly form in the markets in which the entity normally trades. On the other, the net realizable value seems to answer the question of what generalized command over resources, in monetary terms, could be attained by selling one or more assets 
(Bedford \& McKeown, 1972).

Therefore, replacement cost - as an entry value - is perhaps the most useful measure of current value for the need of assessing the ability of a company to remain in business (doing the same sorts of things in the future as in the past) and to pay dividends or pay for expansion without requiring new external financing (Falkenstein \& Weil, 1977). Thus, RC assumes that survival is the basic need of the entity (Bedford \& McKeown, 1972).

On the other hand, net realizable value - as an exit value - seems particularly useful from a decision-making perspective. The resulting information privileges the stockholders' need for knowledge. They would know the amount that could be realized by the corporation and distributed to them through the sale of specific assets (Bedford \& McKeown, 1972; Falkenstein \& Weil, 1977).

Another informative advantage of NRV is that users often refer to a rate of return computation where the measurement of assets influences both numerator and denominator. The latter seems to include the amount for which the assets could be exchanged (NRV) and not the cost of acquiring equivalent assets (RC) (Bedford \& McKeown, 1972). Moreover, since the option of not buying these assets is no longer available, it is not meant to assess management on the bases of an investment they might now refuse. In the same way, to compute the net income (the rate numerator), managers should use NRV and not RC (Bedford \& McKeown, 1972).

It is not negligible, however, that such value logics are not mutually exclusive. These value configurations were also used at the same time, giving rise to value mixed models (MacNeal, 1970; Sprouse \& Moonitz, 1962; Popoff, 1974).

\section{Discussion}

Starting from the 2015 FASB updates, there were the two main scopes: align more closely US GAAP with IFRS standards, and simplify the measurement of inventory, reducing costs and complexities.

As we already said, the convergence between the two accounting standards is just partial. Moreover, Harris and Ananthanarayanan (2019) highlight the remaining doubts about whether the ASU 2015-11simplifies the measurement of inventories.

To evaluate the effectiveness of the convergence process, we analyze whether emerge some differences in the accounting treatment of the inventories under US-GAAP and IAS 2. Per each case, we view the impacts of two accounting treatments in terms of simplification, comparability, cost formula employed, and value measurement theories. We discuss these different aspects referring to the following three cases:

$1^{\text {st }}$ case: US entities that adopt US-GAAP (thereafter US entity or corporation or company) measure inventory only using any method other than LIFO or RIM, compared to IAS-compliant entities use any method other than LIFO.

$2^{\text {nd }}$ case: US entities measure inventory only using LIFO or RIM, compared to IAS-compliant entities use any method other than LIFO.

$3^{\text {rd }}$ case: US entities measure some inventory with LIFO or RIM and some others using FIFO or WAC, compared to IAS-compliant entities use any method other than LIFO.

In the $1^{\text {st }}$ case, the update actually could reduce costs and complexities of the accounting treatment, aligning the inventory measurement with IFRS standards (except in the case in which IAS-compliant entity uses the RIM, fact involved in $2^{\text {nd }}$ case). In the subsequent measurement, all the corporations have to apply only the LCNRV principle, where the NRV, under US GAAP, is defined in a quite similar way to IAS 2.

In the $\mathbf{2}^{\text {nd }}$ case, US entities have to adopt only the LCM principle. According to Daraghma (2018), three different outcomes depending on which value is assigned to the market: replacement cost (RC), NRV (also defined as "ceiling" or "upper limit") or net realizable value less profit margin (NRV-PM, also described as "floor" or "lower limit"). In this scenario, for a US corporation, nothing has changed respect to the previous ARB 43; pre-existing costs and complexities cannot have been reduced (Penner et al., 2016). Moreover, the accounting treatments under US-GAAP and IAS 2 are not comparable. US entities use a cost formula (LIFO) that is prohibited by the IASB and have to apply the LCM (not LCNRV) principle for evaluating ending inventories.

Correctly, regarding the cost formula (LIFO) applied, it, as an income-statement-oriented method, provides a timelier measure of firm performance (Houmes et al., 2012; Flood, 2019), and consequently misrepresents market conditions and up-to-date information of the ending asset (Reineking et al., 2012). Conversely, the cost formulas suggested by the IAS 2 are consistent with the asset-liability approach adopted by the IASB at the beginning of the 2000s, which focuses on the account balance on a day-to-day basis. It requires that figures on 
the financial statement represent the most relevant information regarding time (Reineking et al., 2012).

Referring to the subsequent measurement, we examine the following LCNRV and LCM principles, respectively, under IAS 2 and ASU 2015-11, highlighting the emerging differences.

IAS 2, adopting a prudential valuation approach (Bao et al., 2010; Barker \& McGeachin, 2015; Barker \& Teixera, 2018), requires inventory to be measured at the LCNRV. It means not defer to the future period, costs that are totally, or partially, non-recoverable. The standard states that, for example, if following a reduction in sales prices or an increase in estimated costs for the completion of the product, or due to the obsolescence of the goods in storage, the NRV was lower than the relative expense, the inventories must be written down by aligning the book value with this lower value.

Crucial is to understand the determination of NRV.

Under IAS 2, the term 'net realizable value' is defined as "the estimated selling price in the ordinary course of business less the estimated costs of completion and the estimated costs necessary to make the sale" (IAS 2, p. A983; Harris \& Ananthanarayanan, 2019). Prima facie, the NRV could be assimilated to the fair value, but it is not correct. Fair value is defined as "the price that would be received to sell an asset or paid to transfer a liability in an orderly transaction between market participants at the measurement date" (IFRS, 13). Hence, NRV is the estimated price, and so refers "to the net amount that an entity expects to realize" (IAS 2, 2003: A983). At the same time, the fair value reflects the price at which to sell the same inventory in the principal (or most advantageous) market for that inventory would take place between market participants at the measurement date (exit value). Therefore, NRV is an entity-specific value (Walton \& Aerts, 2006). Fair value reflects an exit-price notion (Lee, 1974; Alexander, 2012; Walton, 2012; Magnan, Menini \& Parbonetti, 2015).

Then, the subsequent measurement does not result in a simple comparison between cost and market value, but implies a more sophisticated estimate of the amount that the company expects to realize from inventories under normal circumstances and on a standard production level (IAS 2, p.A983).

Besides, IAS 2 specifies that (Onyekwelu \& Boniface, 2014):

- $\quad$ regarding finished goods, partially finished goods, work in progress (hereafter, "output"), the NRV is equal to the price presumably obtainable from the direct sale of goods under normal conditions, net of the additional costs of completion and direct sales expenses;

- regarding raw materials and other supplies held for use in the production of inventories (hereafter, "input"), the replacement cost (RC) of the raw materials may be the best available measure of their NRV (IAS 2, p.A987).

The problem of determining NRV, often calculated as the market price net of sales costs, appears relevant. Such modus operandi does not seem to take into account the normal going of a company, associating this definition with that also contemplated by the IASB of fair value minus sales costs that have replaced that of the net selling price (Alexander, 2007).

The IASB concerning inventories requires an assessment at the NRV, or a specific value for the company other than the market price minus the related selling costs.

The question has not a peaceful solution, especially regarding the ability of the value above to represent the phenomenology of the company. In July 2006, the EFRAG, by its comment letter on the "Measurement on Initial Recognition" discussion (IASB, 2005), does not share the arguments provided to support that a measurement on market values, may be more representative of the company phenomenology than a specific value (entity-specific value) (Alexander, 2007).

Conversely, it is deeply entrenched in the Anglo-Saxon literature and practices, the assumption that a current value reflects, even if indirectly, the future performances because it discounts the operators' expectations and the existing prospects.

On these premises, determining NRV for outputs seems less complicated than defining NRV for inputs. The latter appears to be a relevant issue, given that it is more subject to internal manipulation and subjectivity (Harris \& Ananthanarayanan, 2019). There is a difficulty in estimating the probable future revenue related to the sale of products made with these inputs and all the additional production costs necessary to complete the output when the production process has not yet started or has just started.

The choice of RC, in an inputs write-down hypothesis, therefore, is also justified for the immediacy of the evaluation. Not surprisingly, the IAS 2 defines RC not as being a specific method to determine inputs value, but as the best objective estimate of the NRV of inventories, if the latter is lower than their costs. 
Undoubtedly, in this way, IAS 2 does not define a univocal recognition criterion for the value to compare to the cost. The international standard always exhorts to calculate both values, establishing that an RC lower than the cost does not always imply a write-down (IAS 2, 2003: A987).

Therefore, even if RC is lower than historical cost, the inventories are not written down, if NRV of the finished goods, in which they will be incorporated, is greater than or equal to its cost of production (entity expects to sell at or above production cost the finish goods). Otherwise, inventories are written down to NRV.

According to IAS 2, the raw materials (inputs) are evaluated not directly at the RC - as the best estimate of the NRV - but at NRV of the finish goods minus the additional costs of completion.

The choice between NRV and RC does not involve just the accounting level but also the significance of the value through the value measurement theories.

The example following could help to understand the LCNRV principle under IAS 2.

Table 3. Determination of NRV: compare and contrast

\begin{tabular}{l|cc} 
& Hypothesis I & Hypothesis II \\
\hline Purchase cost (PC) & 50 & 50 \\
Replacement cost (RC) & 40 & 40 \\
Further completion costs (FCC) & 10 & 10 \\
Production cost (PC+FCC) & 60 & 60 \\
Net realized value (NRV) & 70 & 35
\end{tabular}

Source: Authors'.

In the $1^{\text {st }}$ hypothesis, although the inventories replacement cost (40) is lower than the purchase cost (50), the amount is not written down because the cost of production of the finish goods produced with the use of these raw materials (60) is entirely recovered from the net realizable value (70). To the same conclusion, we would be arrived comparing the indirect NRV $(60=70 \mathrm{NRV}-10$ FCC $)$ to the purchase cost (50).

In the $2^{\text {nd }}$ hypothesis, the replacement cost (40) of the raw materials is lower than the purchase cost (50). At the same time, the price of inventories plus additional costs for the production of the product (60) is not recovered from the presumable realization of finished goods obtained with the use of these materials (35). Thus, a write-down must be carried out. Nevertheless, the solution is not so clear.

A restrictive application of the net realizable value leads to record a depreciation equal to the difference between the NRV of the product (35) and the cost of production of the goods (60). Thus, the purchase cost of the materials (50), should be reduced to 25 and coincides with NRV (35) minus the additional costs of completion (10).

On the other hand, if we want to interpret IAS 2 to the letter, the NRV to which the cost of ending raw materials should be aligned should be represented by the RC (40). In this case, therefore, we would identify a write-down equal to 10 (= $50 \mathrm{PC}-40 \mathrm{RC})$.

This last solution seems to be the prevailing interpretation both because it allows the immediacy of the evaluation and because estimates of the NRV must also take into consideration the purpose for which the stock is held. Regarding the assessment of input, the company is interested to know the cost to which the asset would be repurchased to guarantee the integrity of production.

Nevertheless, it is reasonable to ask how this accounting behavior is correct in the $2^{\text {nd }}$ hypothesis given that the NRV of finished goods (35) is not able in perspective to regenerate the cash-flow invested for the production, generating a loss of 15 to future years $(40 \mathrm{RC}+10 \mathrm{FCC}-35 \mathrm{NRV}=15)$.

Basing on these assumptions, the assessment of raw materials is not a simple matter.

According to the ASU 2015-11 option for using LIFO or RIM, the US standard, adopting a prudential approach (Bao et al., 2010; Gray \& Ehoff, 2014; Barker \& McGeachin, 2015; Barker \& Teixera, 2018), requires to evaluate the inventories at the LCM principle.

The market value might be assimilated to replacement cost (RC), NRV (also defined as "ceiling" or "upper limit"), or net realizable value less profit margin (NRV-PM, also described as "floor" or "lower limit").

In the $1^{\text {st }}$ hypothesis, a US corporation arrived at the same conclusion of an IAS-compliant entity for determining the market value. 
The NRV is defined in the Master FASB Codification Glossary as "the estimated selling prices in the ordinary course of business, less reasonably predictable costs of completion, disposal and transportation" (ASU 2015-11, p. 330-10-35-1B), quite similar to the NRV defined by IAS 2 .

The conclusion is not the same in the $2^{\text {nd }}$ hypothesis. The US-GAAP establishes that when the utilities of inventory are lower than its costs, the difference shall be recognized as a loss of a current period. In these circumstances, the LCM principle leads to measure the residual usefulness of an inventory expense, usually represented by the market value.

According to the US standard, the market value is equal to the current replacement cost. Still, it may not exceed net realizable value (selling price in normal business minus reasonable costs of completion and disposal), or be less than net realizable value minus the normal profit margin (Flood, 2019). One exception to the LCM principle is that if there were any evidence that sales would occur at a fixed price, even if the current replacement cost is lower than actual cost, then such a loss would not be recognized.

Correctly, in the ASU 2015-11, the term "market" is used as a standard term that identifies a range from NRV to NRV minus the costs of completion and the expected or normal profit margin (NRVPM), obtainable from a sale, in which the RC should generally fall in (See Figure 1).

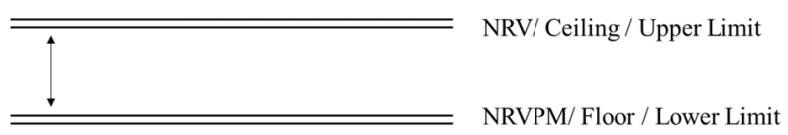

Figure 1. Market value as a range

Market value (MV) is equal to:

i NRV, if RC is higher than the floor;

ii NRV minus estimated profit margin, if RC is lower than the ceiling;

iii RC, if this last one is ranging from floor to ceiling.

According to both international accounting settings, for the inputs, the RC is the first reference to estimate the extra-accounting value of the inventory. The RC seems to be a valid indicator of the future economic utilities of an ending asset. It is presumed that an incremental/decremental change in the purchase cost of the asset is generally reflected proportionally in the corresponding sales prices.

Thus, the RC constitutes the extra-accounting value to be compared with the inventory book value if it is involved in the range between floor and ceiling.

The LCM principle aims to not attribute abnormal income performance to the subsequent periods (Gray \& Ehoff, 2014):

- The ceiling, or upper limit, provide safeguards to do not recognize excessive future losses, overestimating the carrying amounts of inventories and;

- The floor, or lower limit, provide assurances to do not recognize excessive future (abnormal) profits, underestimating the carrying amounts of stocks.

Basing on these assumptions, we analyze the possible relationships between the values mentioned above and the following determinations of the extra-accounting values of the inventories following the LCM principle, trying to understand what could be the best interpretation of the IAS 2 provisions.

Consistent with Flood (2019), in Table 4, we provide the necessary data for the determinations (NRV, RC, and NRV-PM). Successively, in Table 5, we compare the previous values according to the principle of the LCM. Finally, in Table 6, we report, basing on the theoretical level, which accounting behavior to be assumed (write down or not write down, and the value to which align inventory amount) about the possible relationships among NRV, RC, and NRV-PM. 
Table 4. NRV, RC, and NRV-PM data

\begin{tabular}{c|c|c|c|c|c}
\hline & (a) & (b) & (c) & (d) & (e) \\
\hline Good & $\begin{array}{c}\text { Cost } \\
(\epsilon)\end{array}$ & $\begin{array}{c}\text { RC } \\
(\epsilon)\end{array}$ & $\begin{array}{c}\text { Expected sale } \\
\text { price }\end{array}$ & FCC (€) & $\begin{array}{c}\% \text { expected Profit } \\
\text { Margin }\end{array}$ \\
\hline A & 5,00 & 4,60 & 6,00 & 0,70 & $30 \%$ \\
B & 5,00 & 4,60 & 6,00 & 1,00 & $30 \%$ \\
C & 4,00 & 3,30 & 5,00 & 0,30 & $30 \%$ \\
D & 4,00 & 2,60 & 5,00 & 1,00 & $30 \%$ \\
E & 4,00 & 4,50 & 6,00 & 1,00 & $30 \%$ \\
F & 3,00 & 4,50 & 6,00 & 1,00 & $30 \%$ \\
G & 3,00 & 3,70 & 7,00 & 2,00 & $30 \%$ \\
H & 3,00 & 2,90 & 6,00 & 1,00 & $30 \%$ \\
I & 2,00 & 1,80 & 2,20 & 0,50 & $30 \%$ \\
L & 3,00 & 1,60 & 3,10 & 0,50 & $30 \%$ \\
M & 5,00 & 1,70 & 5,50 & 1,00 & $30 \%$ \\
N & 1,00 & 1,50 & 1,20 & 0,50 & $30 \%$ \\
O & 3,00 & 3,80 & 4,00 & 0,50 & $30 \%$ \\
\hline
\end{tabular}

Source: Authors’.

Table 5. Application of LCM principle

\begin{tabular}{|c|c|c|c|c|c|}
\hline Good & $\begin{array}{l}\text { Cost } \\
(€)\end{array}$ & $\begin{array}{l}\mathrm{RC} \\
(€)\end{array}$ & $\begin{array}{l}\text { NRV } \\
\text { Ceiling } \\
\text { (c)-(c) }\end{array}$ & $\begin{array}{l}\text { NRV-PM } \\
\text { Floor } \\
\text { (c)-(d)-(e) }\end{array}$ & $\begin{array}{l}\text { Extra-accounting } \\
\text { Value } \\
\text { Market }\end{array}$ \\
\hline A & 5,00 & 4,60 & $5,3 c$ & 3,80 & 4,60 \\
\hline B & 5,00 & 4,60 & $5,0 \mathrm{C}$ & 3,50 & 4,60 \\
\hline C & 4,00 & 3,30 & $4,7 c$ & 3,50 & 3,50 \\
\hline D & 4,00 & 2,60 & $4,0 c$ & 3,40 & 3,40 \\
\hline E & 4,00 & 4,50 & $5,0 \mathrm{C}$ & 3,80 & 4,50 \\
\hline F & 3,00 & 1,50 & $5,0 c$ & 1,10 & 1,50 \\
\hline G & 3.00 & 3.70 & $5.0 \mathrm{C}$ & 4.10 & 4.10 \\
\hline H & 3,00 & 2,90 & $5,0 c$ & 4,10 & 4,10 \\
\hline I & 2,00 & 1,80 & $1,7 \mathrm{C}$ & 1,10 & 1,70 \\
\hline L & 3,00 & 1.60 & $2.6 \mathrm{C}$ & 1,70 & 1.70 \\
\hline M & 5,00 & 1,70 & $4,5 \mathrm{C}$ & 3,00 & 1,70 \\
\hline $\mathrm{N}$ & 1,00 & 1,50 & $0,7 \mathrm{C}$ & 0,40 & 0,70 \\
\hline o & 3,00 & 3,80 & $3,5 \mathrm{C}$ & 2,60 & 3,50 \\
\hline
\end{tabular}

Source: Authors'

Comparing the results found by the application of the LCNRV (under IAS 2) and LCM (under ASU 2015-11, option using LIFO or RIM), we sometimes observe different accounting solutions (written-down/non-written-down). Occasionally different non-accounting values to compare the inventory cost for defining if it is necessary a written-down or not (see Table 7).

Table 6. Possible relationships between C, RC, NRV, and NRV-PM

\begin{tabular}{|c|c|c|c|c|}
\hline \multirow{2}{*}{ Good } & \multirow{2}{*}{$\begin{array}{c}\text { Possible relationship } \\
\text { between } \\
\text { C, RC, NRV, NRV-PM }\end{array}$} & \multicolumn{3}{|c|}{$\begin{array}{l}\begin{array}{l}\text { Evaluation of inventories according to LCM principle } \\
\text { - witi identification of market velue - }\end{array} \\
\end{array}$} \\
\hline & & $\mathrm{RC}$ & NRV & NRV-PM \\
\hline A & $\mathrm{NRV}>\mathrm{C}>\mathrm{RC}>\mathrm{NRV}-\mathrm{PM}$ & Market-down & & \\
\hline B & $\mathrm{NRV}=\mathrm{C}>\mathrm{RC}>\mathrm{NRV}-\mathrm{PM}$ & Market-down & & \\
\hline C & $\mathrm{NRV}>\mathrm{C}>\mathrm{NRV}-\mathrm{PM}>\mathrm{RC}$ & & & Market-down \\
\hline D & $\mathrm{NRV}=\mathrm{C}>\mathrm{NRV}-\mathrm{PM}>\mathrm{RC}$ & & & Market-down \\
\hline E & $\mathrm{NRV}>\mathrm{RC}>\mathrm{C}>\mathrm{NRV}-\mathrm{PM}$ & No Market-down & & \\
\hline $\mathrm{F}$ & $\mathrm{NRV}>\mathrm{RC}>\mathrm{NRV}-\mathrm{PM}>\mathrm{C}$ & No Market-down & & \\
\hline G & $N R V>N R V-P M>R C>C$ & & & No Market-down \\
\hline H & $\mathrm{NRV}>\mathrm{NRV}-\mathrm{PM}>\mathrm{C}>\mathrm{RC}$ & & & No Market-down \\
\hline I & $\mathrm{C}>\mathrm{RC} \gg \mathrm{NRV} \vee \mathrm{NRV} V \mathrm{PM}$ & & Market-down & \\
\hline $\mathrm{L}$ & $\mathrm{C}>\mathrm{NRV}>\mathrm{NRV}-\mathrm{PM} \gg \mathrm{RC}$ & & & Market-down \\
\hline M & $\mathrm{C}>\mathrm{NRV}>\mathrm{RC}>\mathrm{NRV}-\mathrm{PM}$ & Market-down & & \\
\hline $\mathrm{N}$ & $\mathrm{RC}>\mathrm{C}>\mathrm{NRV}>\mathrm{NRV} V \mathrm{PM}$ & & Market-down & \\
\hline o & $\mathrm{RC}>\mathrm{NRV}>\mathrm{C}>\mathrm{NRV}-\mathrm{PM}$ & & No Market-down & \\
\hline
\end{tabular}

Source: Authors’. 
Table 7. Comparison of results of LCM and LCNRV principles application

\begin{tabular}{|c|c|c|c|c|c|}
\hline \multirow[t]{2}{*}{ Good } & \multicolumn{3}{|c|}{$\begin{array}{l}\text { Eval. of inventories according to LCM principle and } \\
\text { market value }\end{array}$} & $\begin{array}{l}\text { Eval. of inventories } \\
\text { according to LCNRV } \\
\text { principle }\end{array}$ & \\
\hline & $\mathrm{RC}$ & NRV & NRV - PM & RC o NRV & \multirow{5}{*}{ Diferent accounting solution } \\
\hline A & Write-down. & & \multirow{6}{*}{$\begin{array}{l}\text { Write-down } \\
\text { Write-down }\end{array}$} & \multirow{13}{*}{$\begin{array}{l}\text { No Write-down } \\
\text { No Write-down } \\
\text { No Write-down } \\
\text { o Write-down. } \\
\text { No Write-down } \\
\text { No Write-down } \\
\text { oo Write-down } \\
\text { o Write-down } \\
\text { Write-down } \\
\text { Write-down } \\
\text { Write-down } \\
\text { Write-down } \\
\text { o Write-down }\end{array}$} & \\
\hline в & Write-down. & & & & \\
\hline $\mathrm{c}$ & \multirow{8}{*}{$\begin{array}{l}\text { No Write-down } \\
\text { No Write-down }\end{array}$} & & & & \\
\hline D & & & & & \\
\hline E & & & & & \\
\hline $\mathrm{F}$ & & & & & different non-accounting value \\
\hline G & & \multirow{4}{*}{ Write-down } & \multirow{2}{*}{$\begin{array}{l}\text { No Write-down } \\
\text { No Write-down }\end{array}$} & & \\
\hline H & & & & & \\
\hline I & & & & & Same accounting solution, non- \\
\hline $\mathrm{L}$ & & & Write-down & & accounting value doesn't always \\
\hline M & Write-down & & & & \\
\hline $\mathrm{N}$ & & Write-down & & & \\
\hline o & & No Write-down & & & \\
\hline
\end{tabular}

Source: Authors'.

Evaluating the asset $\mathrm{A}$ in stock (in this case the asset is an input of production) under LCNRV principle, we note that the expected selling price (6.00) is higher than the production cost of the goods produced with the participation of asset A $(5.70=5.00$ (a) +0.70 (d)). The outcome would be a non-write-down of the asset.

The result is different from the LCM principle. In this circumstance, it should be assumed that the company is operating under conditions of non-normality as it faces a profit margin equal to zero against a trend performance represented by $30 \%$ of the cost of the asset $(1.5=30 \%$ (e) $* 5.00$ (a)). Therefore, under these conditions, the non-accounting value that would allow the company to allocate the same profit margin to subsequent years is equal to NRV-PM $(3.80=5.30$ minus 1.50$)$. In this case, the solution proposed by ASU 2015-11 is to write-down to the RC (4.60). This solution allows, on the one hand, to not attribute excessive losses to future periods, as if using the NRV, and, on the other, to not excessively depress the future economic results as if using the NRV-PM. In fact, with this solution, the established practice of overseas seems to simply reiterate that the PM of $30 \%$ cannot be maintained under normal operating conditions.

Even more significant for our consideration is the case connected to good I, substantially identical to the $2^{\text {nd }}$ hypothesis reported in Table 3. Applying the LCM principle provides a depreciation of the inventories up to the indirect NRV, as shown in Table 5.

In terms of value measurement theories, the choice of the IAS 2 to require the LCNRV principle appears coherent with a principle-based approach as sometimes associated with the IFRS setting (Nobes, 2015).

With particular regard to the inventories, the IASB prohibited the LIFO as a method of inventory valuation. This was in response to the shift of IFRS from an income statement focus on a balance sheet focus that means focuses on account balances on a day-to-day basis. The balance sheet approach requires that figures on the statement of financial position represent the most relevant information regarding time. Thus, this approach emphasizes the present market conditions for the balance sheet and not the income statement (Reineking et al., 2012). According to the authors, using net realizable value, as an exit value, could inform the stakeholders on the amount that could be realized and potentially distributed by the corporation (Bedford \& McKeown, 1972). These authors define the NRV as the implicit current investment because it is the amount that management refuses to accept in exchange for the assets. It is not a coincidence that IAS 2 defines the RC as the best estimate of the NRV for the inputs, but not the extra-accounting value to compare the recorded cost of the inputs.

On the other hand, the choice of the ASU 2015-11 to maintain a two-tier approach and continue to use LIFO and the LCM principle appears more complicated to explain from a logical perspective.

The LCM principle application, when assuming that a company is using the services in its assets in their internal use, prescribes the use of the RC only if it is between NRV and RV-PM. A decision to replace should be made if the current replacement cost of the services being used is less than the net realizable value of the asset held. This situation should occur in perfect markets, only when the asset held can provide more than one service. If the asset offers only one type of service, the replacement cost of the service will not be less than the net realizable value since firms would immediately replace and sell until the values were realigned (Bedford \& McKeown, 1972). The management needs to be aware continually of both net realizable value and the current replacement cost of each asset held. This conclusion would support the preparation of reports using measurements based on both net realizable value and the current replacement cost. The use of two values should help management in the decision-making process regarding the asset destination. Undoubtedly, this logic is more consistent with the 
income approach of the US GAAP standard (Reineking et al., 2012). Nevertheless, the LMC of the ASU 2015-11 tends to use NVR and RC as interchangeable values, without forgetting that the VRN belongs to the family of exit values while the RC to the family of entry values. The US-GAAP accounting choice could be justified by a continued focus on the income statement view. The application of the replacement cost assumes that survival is a basic need of the entity as a going concern. Survival implies that the firm has the capability to replace used services. In this view, the income does not necessarily mean the excess of one balance sheet over another since only part of the increase would qualify as income (Bedford \& McKeown, 1972).

In the 3rd case, the update requires to use both LCM and LCNRV principles. In this case, Penner et al. (2016) outline that the update could even increase costs and complexities and decrease financial statement comparability, not only in comparing the accounting treatment under IAS 2 and ASU 2015-11, but inside the same financial reporting.

In compliance with the US standard, the same cost formula does not need to be applied to all inventories that have similar nature and use to the entity. It implies that in the same financial statement, there are inventories evaluated at LIFO and all the others different from it.

This approach reduces the informative meaning of the items. As already said, a LIFO evaluation focuses the attention on current income. In contrast, a FIFO or WAC evaluation focuses the emphasis on the present value of the ending assets at the balance sheet date. The mixed-use of both criteria leads to alter the interpretative meaning of the inventories value that represents just a mere accounting data. The information can only be recovered indirectly by recalculating the cost, considering the LIFO reserve disclosed in the notes.

In terms of value measurement theories, the same considerations apply the $2^{\text {nd }}$ case.

\section{Conclusions}

In 2015, the FASB amended an update of the ASU 330 Inventory (ASU 2015-11) to simplify the measurement of inventories and to align their accounting treatments to IAS 2.

In this study, we purpose to explore the real state of convergence between the two accounting standards, analyzing theoretical and practical aspects deriving from their application.

Contrarily to the primary scope of the amendment, the IAS 2 and the ASU 2015-11 do not appear completely align. The US standard allows corporations to evaluate their inventories using LIFO, that was banned by IAS 2 in 2003, (Henry \& Holzmann, 2010; Houmes et al., 2012; Penner et al., 2016; Harris \& Ananthanarayanan, 2019). This discretion was justified because of both the higher transaction's costs of its repeal and tax matters (Husband, 1940; Jennings et al., 1986; Dopuch \& Pincus, 1988; Cushing \& LeClere, 1992; Reineking et al., 2012; Gray \& Ehoff, 2014).

In this research, we analyze three different cases that emerge when we compare the inventories accounting treatment under US-GAAP and IAS 2. Per each case, we view the impacts of two accounting treatments in terms of simplification, comparability, cost formula employed, and value measurement theories.

The case that shows the most controversial issues is the $2^{\text {nd }}$ case and, only in a consequential way, the $3^{\text {rd }}$ case, for which the same consideration is applied.

In the $2^{\text {nd }}$ case, we evidence that the option to use LIFO of the ASU update does not reduce the complexity of the evaluation, which does not lead to a real convergence with the IAS 2 .

Regarding the choice to continue to use LIFO, besides, to strictly accounting reasons related to adopting an income statement approach, the most significant impediment to these companies changing from LIFO is the tax implications. Not only will the cessation of LIFO cause the individual tax burden on companies to rise, but the costs of switching to another method and costs of accounting for prior years' reports are substantials (Reineking et al., 2012). To use LIFO for tax reporting purposes, a US-GAAP-compliant company must also use LIFO for financial reporting purposes. This is called the LIFO conformity requirement (Barry, Kuykendall, \& McClements, 2009). Because IFRS does not allow LIFO as a method for financial reporting purposes, the discontinuance would force companies also to discontinue using LIFO for tax reporting purposes.

To convert from one method to another, a company must obtain approval from the IRC. The translation across methods in the financial statement should be applied retroactively to prior year statements.

If LIFO is eliminated, all of the tax burdens that were deferred across time will be brought up to the present and must be accounted for (Leone 2010). The dramatic increase in gross income for a company shifting from LIFO to another method would be a one-time occurrence. 
Based on this assumption, it is evident that the option to use LIFO establishes a two-tier approach for the accounting treatment of inventory (Harris \& Ananthanarayanan, 2019), which could be defined as being an "accounting loophole."

The comparing of the ASU 2015-11 option and the IAS 2, highlights the determination of NRV as a specific entity value and the calculation of the extra-accounting value to which align the cost in the write-down case as main critical issues.

In particular, this determination is not only an accounting issue. It influences the informational capacity of the financial statements and, therefore, their ability to represent the phenomenology of an entity. In this sense, we have noted an inconsistency between theory and practice. IAS 2 defines NRV as a specific value (the estimated selling price). However, the operational difficulties of its determination push practitioners to assimilate this one to the market prices (fair value less cost to sell) at the time of valuation (Alexander, 2007).

Concerning the NRV amount to which align the cost of inputs' production in the write-down hypothesis, the suitability of the replacement cost measure for the NRV seems to be almost undeniable (Flood, 2019). It is necessary to recall that, being an input destined for internal use, the only information that a company may be interested in is the cost of repurchasing the asset to maintain its physical capital unchanged. Nevertheless, in the hypothesis in which the NRV-PM it is to record in the balance sheet a value that is not fully recoverable. Valuation of raw materials, at the $\mathrm{RC}$, in this case, would result in lower earnings due to an asset overestimation in subsequent years. It is reasonable to ask whether, by this reasoning, an alignment of the cost of inventories to the NRV-PM of the asset should be preferred. This position appears to be consistent also with the logic of the evaluative prudence principle accepted by both Boards, which chooses the one that has the highest probability of verification in identifying the non-accounting value, mainly linked to the reliability of the information. It is not negligible, however, that, in this case, we move below the cost, affecting the measure of income for the period. If the RC is greater than the expected benefits (for a sufficiently reliable indirect NRV value), a higher, not fully justified, value is attributed to the result for the year. The nature of the specific value (Walton \& Aerts, 2006) required by both Boards and the general orientation of their balance sheet to represent the ability to generate cash flows seems to favour the prevalence of the concept of financial resources recovery.

Finally, we can conclude that a legitimacy gap may explain the likely failure to reach full convergence between the two standards (De Luca \& Prather-Kinsey, 2018). The US jurisdiction probably hinders the incorporation of IFRS instantly as its national accounting as issued by the IASB.

De Luca and Prather-Kinsey (2018) posit that currently, US-GAAP and IFRS are basically competing within the US capital market for cross-listed firms' "adoption". Furthermore, the co-endorsement process has resulted in different versions of IFRS being accepted across different national jurisdictions. If there is a legitimate international regulator (IR) that polices and enforces IFRS as published by the IASB, then the adoption of IFRS globally could be achieved.

The paper presents several practical and theoretical implications for the academic community and policymakers as well as regulators and users.

The findings of this study can be useful for regulators. If the convergence is the real target of the Boards, it is crucial to start from the differences, and the reasons still existing between the ASU 330 updated and the IAS 2. An international regulator, legitimate by national regulators, would have to be identified to police and enforce IFRS as published by the IASB (De Luca \& Prather-Kinsey, 2018). One of the significant demands of report users is the comparability among entities. They would find any valuation which purports to reveal unique information to support the decision-making process.

\section{References}

Alexander, D. (2007). Globalisation of accounting standards: a UK perspective. Globalisation of accounting standards, 46-63.

Alexander, D. (2012). Recent history of fair value. In The Routledge companion to fair value and financial reporting (pp. 85-104). Routledge.

Alibhai S., Bakker, E., \& Balasubramanian, T. V. (2019). Interpretation and application of IFRS standards. Wiley.

Bao D., Lee J., \& Romeo, G. (2010). Comparison on selected ratios between IFRS and US GAAP companies, Journal of Financial Reporting and Accounting, 8(1), 22-34. https://doi.org/10.1108/19852511011055925

Barker, R., \& McGeachin. (2015). An Analysis of Concepts and Evidence on the Question of Whether IFRS 
Should be Conservative. Abacus, 51(2), 169-207. https://doi.org/10.1111/abac.12049

Barker, R., \& Schulte, S. (2017). Representing the market perspective: Fair value measurement for non-financial assets, Accounting, Organisations and Society, 56, 55-67. https://doi.org/10.1016/j.aos.2014.12.004

Barker, R., \& Teixera, A. (2018). Gaps in the IFRS Conceptual Framework. Accounting in Europe, 15(2), 153-166. https://doi.org/10.1080/17449480.2018.1476771

Barry, J., Kuykendall, K., \& McClements, T. (2009). The Uncertain Future of LIFO. New York: Price Waterhouse Coopers LLP.

Barth, M. E. (2014). Measurement in financial reporting: The need for concepts, Accounting Horizons, 28(2), 331-352. https://doi.org/10.2308/acch-50689

Baudot, L. (2018). On commitment toward knowledge templates in global standard setting: The case of the FASB-IASB Revenue Project. Contemporary Accounting Research, 35(2). 657-695. https://doi.org/10.1111/1911-3846.12396

Bedford, N. M., \& McKeown, J. C. (1972). Comparative analysis of net realizable value and replacement costing. The Accounting Review, 47(2). 333-338

Biddle, G. C. (1980). Accounting Methods and Management Decisions: The Case of Inventory Costing and Inventory Policy. Journal of Accounting Research, 18, 235-280.

Camfferman, K., \& Zeff, S. A. (2018). The challenge of setting standards for a worldwide constituency: Research implications from the IASB's early history. European Accounting Review, 27(2). 289-312. https://doi.org/10.1080/09638180.2017.1296780

Coffee, D., Roig, R., Lirely, R., \& Little, P., (2010). The materiality of LIFO accounting distorsion on liquidity measurements. Journal of Finance and Accountancy, 2(1), 1-12.

Cushing, B. E., \& LeClere, M. J. (1992). Evidence on the determinants of inventory accounting policy choice. The Accounting Review, 67(2), 355-366.

Daraghma Z., (2018). Expectation Gap in Applying the Ias 2 [Inventories]: Evidence from Palestine. Academy of Accounting and Financial Studies Journal, 22(2), 1-16.

De Luca, F., \& Prather-Kinsey, J. (2018). Legitimacy theory may explain the failure of global adoption of IFRS: the case of Europe and the US Journal of Management and Governance, 22(3), 501-534. https://doi.org/10.1007/s10997-018-9409-9

Deloitte. (2019). Key differences between USS GAAP and IFRS Standards Inventories.

Dopuch, N., \& Pincus, M. (1988). Evidence choice of inventory accounting methods: LIFO versus FIFO. Journal of Accounting Research, 26(1), 28-59.

Edwards, E. O. (1975). The state of current value accounting. The Accounting Review, 50(2), 235-245.

EY. (2019). International GAAP 2019, Generally Accepted Accounting Principles under IFRS. Ernst \& Young.

Falkenstein, A., \& Weil, R. L. (1977). Replacement cost accounting: What will income statements based on the SEC disclosures show?-Part I. Financial Analysts Journal, 33(1), 46-57.

FASB. (2015). Topic 330 No. 2015-11 (ASU 2015-11). Inventory. Financial Accounting Standard Board.

Flood, J. M. (2019). GAAP 2019: Interpretation and Application of Generally Accepted Accounting Principles. Chapter 23: ASC 300, Inventory.

Gee, K. P., \& Peasnell, K. V. (1976). A pragmatic defence of replacement cost. Accounting and Business Research, 6(24), 242-249.

Giganti, G. (1990). Criteria of inventory pricing. Engineering Costs and Production Economics, 19, 175-181.

Gray, D. (2013). IFRS and US GAAP convergence progressing: As taxpayers voluntarily stop using LIFO. International Business \& Economics Research Journal, 12(4), 451-456. https://doi.org/10.19030/iber.v12i4.7743

Gray, D., \& Ehoff, Jr. C. (2014). Lower of cost or market inventory valuation: IFRS versus US GAAP. Journal of Business and Economic Research, 12(1), 19-22. https://doi.org/10.19030/jber.v12i1.8372

Guenther, D. A., \& Sansing, R. C. (2012). Unintended Consequences of LIFO Repeal: The Case of the Oil Industy. The Accounting Review, 87(5), 1589-1602. https://doi.org/10.2308/accr-50194 
Harris, P., \& Ananthanarayanan, U. (2019). Inventory Costing: A comprehensive case study. Review of business \& finance studies, $10(1), 15-24$.

Henry, E., \& Holzmann, O. J. (2010). LIFO costing for inventory: A key area of non-convergence. Journal of Corporate Accounting \& Finance, 21(5). 73-78. https://doi.org/10.1002/jcaf.20615

Horngren, C. T. (1965). How Should We Interpret the Realization Concept? The Accounting Review, $40(2), 323$.

Houmes, R., Dickins, D., \& O'Keefe, R. (2012). New evidence on the incremental information content of earnings reported using the LIFO inventory method. Advances in Accounting, 28(2), 235-242. https://doi.org/10.1016/j.adiac.2012.09.005

Husband, G. R. (1940). First-in, Last-out Method of Inventory Valuation. The Accounting Review, 15(2), 190-196.

IASB. (2005). IAS 2, Inventories. International Accounting Standard Board.

IASB. (2011). IFRS 12, Fair Value Measurement. International Accounting Standard Board.

Ijiri, Y., \& Jaedicke, R. K. (1966). Reliability and objectivity of accounting measurements. The Accounting Review, 41(3), 474-483.

Ijiri, Y., \& Noel, J. (1984). A reliability comparison of the measurement of wealth, income, and force. Accounting Review, 52-63.

Jennings, R., Simko, P. J., \& Thompson II, R. B. (1996). Does LIFO Inventory Accounting Improve the Income Statement at the Expense of the Balance Sheet? Journal of Accounting Research, 34(1), 85-109.

Jones, S. (2015). The Routledge companion to financial accounting theory. New York: Routledge.

Lee, T. (1974). Income and Value measurement (3rd ed.). International Thomson Business Press.

Leone, M. (2010). Sucking the LIFO Out of Inventory. CFO Magazine. Retrieved from http://www.cfo.com/article.cfm/14508745?f=singlepage

Li, J., \& Sun, M. Y. Y. (2016). LIFO distorsions in the manufacturing industry. Accounting and finance research 5(1), 191-201. https://doi.org/10.5430/afr.v5n1p191

Lin, S., Riccardi, W., Wang, C., Hopkin, P. E., \& Kabureck, G. (2018). Relative effects of IFRS adoption and IFRS convergence on financial statement comparability. Contemporary Accounting Research, 6(2), 588-628. https://doi.org/10.1111/1911-3846.12475

Littleton, A. C. (1952). Significance of invested cost. The Accounting Review, 27(2), 167-173.

Littleton, A. C. (1953). [Limitations on the significance of invested cost]: A reply. The Accounting Review, 28(1), 8-11.

Magnan M., Menini, A., \& Parbonetti, A. (2015). Fair value accounting: information or confusion for financial markets? Review of Accounting Studies, 20(1), 559-591.

May, G. O. (1952). Limitations on the significance of invested cost. The Accounting Review, 27(4), 436-440.

Myers, J. H. (1959). The critical event and recognition of net profit. The Accounting Review, 34(4), 528-532.

Nobes, C. W. (2005). Rules-based standards and the lack of principles in accounting. Accounting Horizons, 19(1), 25-34. https://doi.org/10.2308/acch.2005.19.1.25

Onyekwelu, O. L., \& Boniface, V. U. (2014). Effects of IFRS Adoption on Inventory Valuation and Financial Reporting in Nigeria. European Journal of Business and Management, 6(8), 29-34.

Penman, S. H. (2007). Financial reporting quality: is fair value a plus or a minus? Accounting and business research, 37(sup1), 33-44. https://doi.org/10.1080/00014788.2007.9730083

Penner, J., Kreuze, J., Langsam, S. (2016). analysis of simplification of accounting initiative for inventory and update of other simplification proposals. The Journal of Corporate Accounting \& Finance, 27(4), 9-12. https://doi.org/10.1002/jcaf.22155

Popoff, B. (1974). The Informational Value of Replacement Cost Accounting in External Company Reports, in Accounting and Business Research, Winter 1974.

Pw, C. (2019a). Inventory. Price water house coopers.

Pw, C. (2019b). IFRS and US GAAP: similarities and differences. Price water house coopers. 
Reineking, C., Chamberlain, D. H., Rudolph, H. R., Smith, L. M. (2012). An examination of inventory costing convergence under generally accepted accounting principles and international financial reporting standards. Journal of International Business Research: 1-21.

Reinstein, A., Alvin, G., Vangermeersch, R. G. (2008). George R.Husband: Contributions to the development of Accounting thought. Abacus, 44(1), 82-108. https://doi.org/10.1111/j.1467-6281.2007.00250.x

Richardson, A. J., \& Eberlein, B. (2011). Legitimating transnational standard-setting: The case of the International Accounting Standards Board. Journal of Business Ethics, 98(2), 217-245. https://doi.org/10.1007/s10551-010-0543-9

Sedki, S. S., Smith, A., Strickland, A. (2014). Differences and similarities between IFRS and GAAP on inventory, revenue recognition and consolidated financial statements. Journal of Accounting and Finance, 14(2), 120-123.

Shanklin, S. B., Hunter, D. R., \& Ehlen, C. R. (2011). A Retrospective View of the IFRS Conceptual Path and Treatment Of Fair Value Measurements In Financial Reporting. Journal of Business \& Economics Research, 9(3), 23-28. https://doi.org/10.19030/jber.v9i3.4126

Simeon, E. D., \& John, O. (2018). Implication of choice of inventory valuation methods on profit, tax and closing inventory. Account and Financial Management Journal, 3(7), 1639-1645.

Sprouse, R. T., \& Moonitz. (1962). Accounting Research Study, 3, AICPA.

Sterling, R. R. (1981). Costs (historical versus current) versus exit values. Abacus, 17(2), 93-129.

Street, D. L., \& Gray, S. J. (1999). How wide is the gap between IASC and US GAAP? Impact of the IASC comparability project and recent international developments. Journal of International Accounting, Auditing and Taxation, $8(1)$, 133-164.

Suchman, M. C. (1995). Managing legitimacy: Strategic and institutional approaches. Academy of management review, 20(3), 571-610.

Walton, P. (2012). The Routledge companion to fair value and financial reporting. Routledge.

Walton, P., \& Aerts, W. (2006). Global financial accounting and reporting: principles and analysis. Cengage Learning EMEA.

\section{Copyrights}

Copyright for this article is retained by the author(s), with first publication rights granted to the journal.

This is an open-access article distributed under the terms and conditions of the Creative Commons Attribution license (http://creativecommons.org/licenses/by/4.0/). 